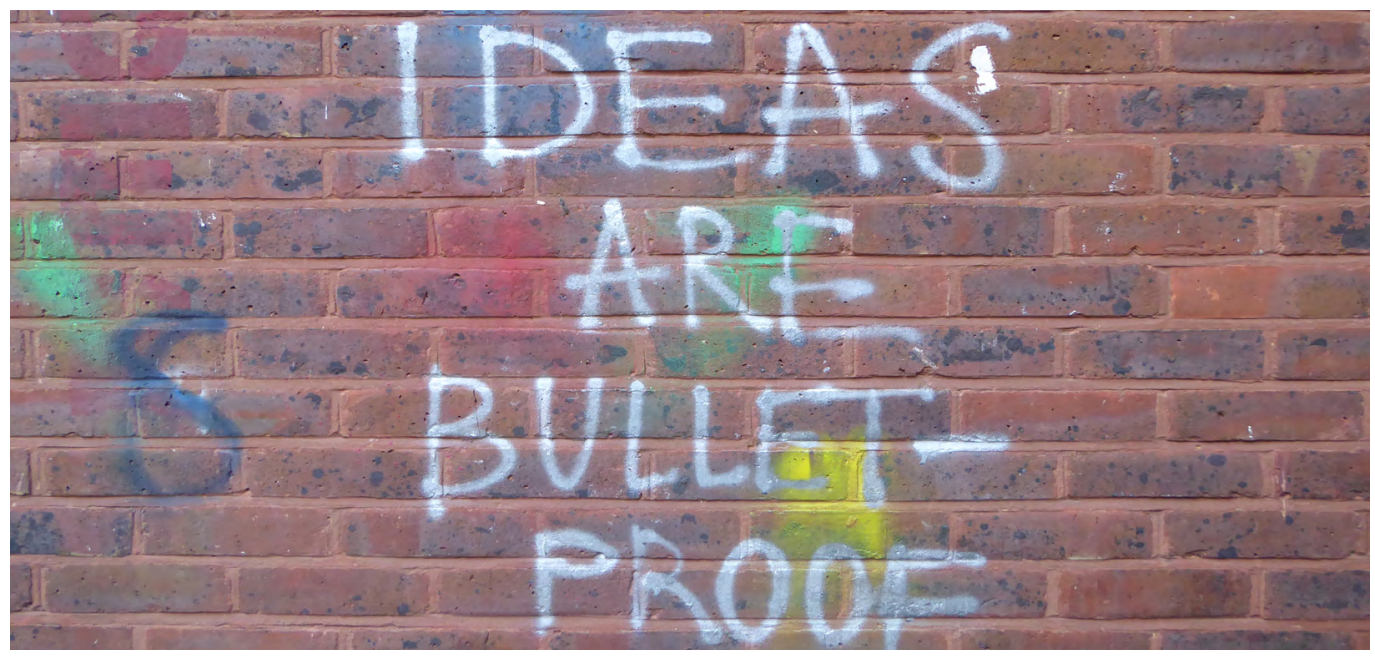

Graffiti on a wall in Hackney Wick, East London. PC: Duncan C (CC).

\section{Ideas Are Bullet-Proof A Conversation with Ching Kwan Lee}

\section{Shui-yin Sharon YAM Ching Kwan LEE}

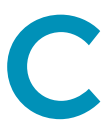

hing Kwan Lee is a sociology professor at the University of California, Los Angeles (UCLA), and former Chung Sze-Yuen Professor of Social Science and chair professor at the Hong Kong University of Science and Technology (HKUST, 2019-21). She is the author of several award-winning monographs on Chinese capitalism and labour, including Gender and the South China Miracle: Two Worlds of Factory Women (University of California Press, 1998), Against the Law: Labor Protests in China's Rustbelt and Sunbelt (University of California Press, 2007), and The Specter of Global China: Politics, Labor and Foreign Investment in Africa (University of Chicago Press, 2017).

In late 2020, while at the HKUST, Lee drew the ire of pro-Beijing media outlets for participating in an online panel with dissidents Joshua Wong, Nathan Law, and scholar-activist Benny Tai. Organised by the United States-based advocacy organisation Hong Kong Democracy Council, the panel was titled 'Is This the End of "One Country Two Systems”?'. Lee opined that Hong Kong was a global city, remarking: 'I think it helps not to think of Hong Kong as a Chinese city. We don't belong to China. We belong to the world.' Her comment was taken out of context by two pro-Beijing newspapers in Hong Kong, which accused her of illegally supporting Hong Kong independence and colluding with 'foreign forces'. Lee forcefully and succinctly denied such allegations, asserting her right 
to express her academic analysis during a lawful public event. Her co-panellists, Tai and Wong, were both subsequently imprisoned for their political activism.

Despite the chilling effect of the National Security Law (NSL) on academic freedom, Lee remains an active scholar and teacher in Hong Kong studies. In this conversation, she discussed her changing relationship with and approach to studying Hong Kong as she worked on her latest monograph, about the 2019 prodemocracy movement. This interview offers a glimpse into how a Hong Kong studies scholar navigates the sociopolitical terrain of repression while producing rigorous research that sheds light on Hong Kong's history and social movements.

Shui-yin Sharon Yam: Can you introduce yourself and your scholarly background for readers who are less familiar with your work? What is your relationship to Hong Kong and Hong Kong studies?

Ching Kwan Lee: I was born and raised in Hong Kong. After I earned my PhD in sociology from University of California, Berkeley, I returned to the Chinese University of Hong Kong, my alma mater, to teach. But I left in 1999 to take up a position at the University of Michigan and then at UCLA, where I am now. The arc of my scholarly career coincided with the rise and opening of China and, quite naturally, as a sociologist, I was drawn to that phenomenon. My dissertation covered Hong Kong, interestingly, as part of southern China's miraculous emergence as the workshop of the world. It was a comparative ethnographic study of factory regimes in Hong Kong and Shenzhen, and the class and gender relations between the first generation of Chinese migrant workers and the last generation of industrialists and factory women in Hong Kong.

Since then, my two book-length projects were squarely on China: labour protests in the rustbelt and sunbelt, and the politics of Chinese investment in Africa. The Umbrella Movement sparked my interest in Hong Kong again, but by then it was a Hong Kong I no longer recognised, let alone understood, and therefore intellectually challenging. I tried to catch up on all the excellent Hong Kong studies scholarship produced during the two decades I was away. I was fortunate to have the help of a team of colleagues who know much more about Hong Kong than I and, together, we produced a volume on the Umbrella Movement, Take Back Our Future: An Eventful Political Sociology of the Hong Kong Umbrella Movement (ILR Press, 2019, co-edited with Ming Sing).

For my colleagues in Hong Kong, the need for Hong Kong studies is self-evident. It's like in the United States: studying the US needs no justification of any kind. But as someone who is in the United States, studying China, Asia, and Africa, I always need to situate these regions and societies in the larger context of theory, history, 
and the world. That double consciousness to me is an asset, not a burden. That's why when I began reading and researching Hong Kong, my vision for Hong Kong studies is a bit different from my colleagues based in Hong Kong. Hong Kong studies cannot just be about Hong Kong; it has to be situated in the larger context of theory, historical forces, and the world.

SSY: Your remark about having to situate non-Western research subjects resonates with me, as I shared similar experiences. The need for non-Western scholars to constantly justify their area of research is emblematic of academia's Eurocentrism. A question I often ponder is how transnational non-Western scholars can effectively navigate this tension without capitulating to Eurocentric tendencies. I am also very excited and interested in your current book project. Can you tell us a bit more about it? How is it influenced by your experiences and/or research interests in Chinese capitalism, labour, and gender?

CKL: The book I am working on begins with an ethnography of the 2019 Anti-Extradition Bill Movement, focusing on what I found to be 'revolutionary' in the context of Hong Kong's history. I will then historicise the ethnography with what Foucault would call a history of the present-identifying not the chronological origin of the movement, but rather traces of past practices and power mechanisms that continue to configure the present. If I succeed, I will hopefully offer a critical understanding of how British and Chinese colonialisms have constituted the fundamental category of the 'political' in Hong Kong, how 2019 represented an epistemic and experiential breakthrough of those legacies (or burdens), not so much among academics but among the people.

I am not revealing too much with such an abstract statement, but I have to re-educate myself about my birthplace. On top of that, writing to me is always a process of discovery and analysis. Before I finish any book, I am not in a position to state my overarching arguments.

SSY: Writing is an iterative process, so in fact I appreciate your hesitancy to mount an overarching claim now.

CKL: For me, this is the most challenging book I have ever written. I need to relearn Hong Kong history through the lens of colonial and postcolonial studies, and to bring my understanding of China and global China to bear on this. So, I'd say my previous work on the Chinese ways of power, both in maintaining stability domestically and on expanding domination overseas, helps me see how this historical juncture is part of a larger China project, with all the uncertain and uneven consequences we have seen elsewhere. 
SSY: Between your current book project and the co-edited anthology Take Back Our Future, what major differences and developments have you noticed about social movements in Hong Kong?

CKL: You should direct this question to my colleagues who study social movements from the perspective of social movement studieshow social media organised and mobilised protesters, how the government has used the police and pro-establishment nongovernmental organisations to launch a counter-mobilisation against protesters, how LIHKG [website] discussion cemented solidarity at the discursive levels, etcetera. For me, 2019 was so much more than a social movement that the questions and analytical categories of the social movement literature do not really capture what happened. Social movement studies have a much narrower focus on mobilisation and organisation, not historicity, political subjectivity, the mechanisms of colonial and postcolonial power. Of course, one can generate useful knowledge about 2019 from the perspective of social movement studies. But was it the essence? It is the equivalent of studying government or the state as a complex organisation using organisational theory. Many sociologists do that, but is the state just another organisation? What do we miss if we analyse it using general sociological theories of organisation as one would use for a corporation or an $\mathrm{NGO}$ ?

SSY: You have written several op-eds and explainers on the Hong Kong protests in prominent US media outlets and are currently working on a monograph about the issue. What roles do you see yourself playing as a scholar and public intellectual who straddles academia and the broader public sphere, and the transnational contexts between Hong Kong and the United States?

CKL: I do not see myself playing the role of public intellectual because I do not think I have the aptitude for public engagement. My ability is in scholarship-a slow-motion mode of knowledge production that hopefully has greater depth and larger scope than opinion pieces that are responsive to current affairs and have more immediate relevance to the public. Those op-eds were all written at the request of news editors. Also, the circumstances in 2019 were so exceptional that I felt I should not let go of those opportunities to explain Hong Kong to the world. But I agree there is an urgent need for public intellectuals capable of transnational and intercultural communication, and who can formulate publicly consumable opinions about rapidly changing current affairs.

SSY: Even though you do not see yourself as a public intellectual, you were treated as such when you came under fire in 2020 for saying that 'Hong Kong belongs to the world', as pro-Beijing news sources misconstrued your statement. You cogently refuted such accusa- 
tions. What was your experience like at the time? Are there any transferable lessons there that would help Hong Kong scholars and public intellectuals-both local and diasporic-navigate the increasingly murky and risky discursive terrain under the National Security Law (NSL)?

CKL: I was attacked not for what I said. What I said provided them an excuse. The Chinese Communist Party (CCP) never cares about what academics say or write. They know we don't have influence in the public. As a party, they worry about organised dissent, or alternative organisational capacity. I was attacked because of my association with Joshua Wong, Nathan Law, Benny Tai, and the Hong Kong Democratic Council (HKDC). I was on the same panel with these high-profile dissidents and was a member of the HKDC advisory board. I resigned from the HKDC when the NSL came into effect. The second attack was derivative of the first: once I became a target of 'interest', people who wanted to demonstrate political loyalty or to score political points went after me again. But my experience was nothing, absolutely nothing, compared with what so many others in Hong Kong have to endure.

SSY: At the time, HKUST noted in a public statement that it respected everyone's freedom of speech as entitled under the Basic Law. This poses a stark contrast with the repression of intellectual freedom and freedom of speech that occurs on college campuses now. What changes do you think we will see in Hong Kong higher education in the coming years, and how will that impact on knowledge production and pedagogy, especially in the social sciences?

CKL: The popular misconception of the 'ivory tower' notwithstanding, universities and academia are never insulated from the rest of society, the economy, or the body politic. Without freedom to speak truth to power or the freedom of association to engage peers around the world, there will be no true scholarship. Politics has moved into Hong Kong academia not just in the appointment or dismissal of faculties and administrators. I fear that knowledge itself-research topics, data collection, arguments-will soon be censored, as has been the case in mainland China. Hong Kong studies will be under particular duress as the political regime will also try to impose a regime of truth about Hong Kong. It is more important now than ever that Hong Kong studies be globalised. Colleagues at various UC campuses and I have just launched a program called 'Global Hong Kong Studies@UC' (www.globalhks-uc.org). Our goal is to understand the global and theoretical relevance, connection, and context of Hong Kong's past and present. It transcends the conventional area studies approach to a particular place, country, or region defined by geographical and jurisdictional boundaries. We have regular seminars, symposiums, book talks, films, and multimedia events that are free and accessible worldwide. Beyond this UC program, there is now an international network of Hong Kong 
studies research units based in different universities called Global Nexus for Hong Kong Studies (www.globalnexushk.org). Such interdisciplinary and international collaboration will hopefully put global Hong Kong studies on the map and allow it to grow in a de-territorialised and free space.

SSY: While the development of an international network of Hong Kong studies scholars is encouraging, social scientists and researchers in Hong Kong face an uphill battle. The first NSL trial hinges on the connotations of the protest slogan 'Liberate Hong Kong, Revolution of Our Times'. Social scientists Eliza Lee and Francis Lee both testified, drawing on their research and expertise. While the NSL clamps down on academic freedom, this case highlights the relevance of social-scientific research to public and legal discourse. What role do you see social scientists playing in the public sphere under the shadow of the NSL?

CKL: Not much, I am afraid. Kudos to Eliza and Francis for making a stand based on empirical research and reasons. Their testimonies were a breath of fresh air into a dying public sphere. But the court's dismissal of their arguments shows that we have entered a very dark time when arbitrary brute force overrides rational debates of right and wrong, true and false. The space for social science research is rapidly closing in Hong Kong, as has been the case for many other authoritarian societies, including mainland China. There was a reason for my own discipline, sociology, to be banned a few years after the CCP took power, only to be revived in the early 1980 s.

Today, powerholders may not need to go to the extreme of banning a field of knowledge. Instead, they could reorganise knowledge production, and restructure faculty lines and employment. This is what I observed at HKUST. Its new Guangzhou campus is organised around 'hubs and thrusts' that are basically think tank-like units serving the government-internet of things, smart manufacturing, intelligent transportation, financial technology, sustainable development, etcetera. No more departments based on long-standing disciplines and global accumulation of knowledge such as physics, chemistry, economics, let alone sociology and political science.

SSY: For Hong Kong and many Hongkongers, the 2019 protests and their aftermath were a watershed moment. Is there anything from that period that continues to resonate with you?

CKL: Among the many innovative and insightful slogans during the 2019 protests, there is one that resonates with me most: 'Ideas are bullet-proof.' It resonates with me because I am in the business of producing ideas. In addition, the regime is very intent on reshaping our ideational worlds-common sense, perception, and history. As we witness movements, institutions, and organisations being crushed every day, it is all the more important that we protect this line of defence. 
This text is taken from Made in China Journal: Volume 6, Issue 3, 2021, edited by Ivan Franceschini, Nicholas Loubere and Shui-yin Sharon Yam, published 2022 by ANU Press, The Australian National University, Canberra, Australia.

doi.org/10.22459/MIC.06.03.2021.17 